\title{
EFFECT OF MINERAL AND BIO-FERTILIZATION ON YIELD, YIELD COMPONENTS AND QUALITY TRAITS OF SUGAR BEET PLANTS
}

\author{
Essam A. Sharaf ${ }^{1}$; Dalia E. El-Geddawy ${ }^{2}$; \\ Mohsen A. Badawi ${ }^{3}$ and Ragab A. Dawood ${ }^{4}$
}

1- Agricultural Research at Delta Sugar Company, El-Hamol, Kafr El-Sheikh, Egypt.

2- Sugar Crops Research Institute, Agric. Res. Center, Cairo, Egypt.

3- Agronomy Department, Mansoura Univ., Mansoura, Egypt.

4- Agronomy Department, Assiut Univ., Assiut, Egypt.

\section{ABSTRACT}

Two field experiments were carried out at the Agricultural Research Farm of Delta Sugar Company at El-Hamol, Kafr El-Sheikh Governorate during two winter seasons of 2008/2009 and 2009/2010 to study the effect of mineral and bio-fertilization on yield and its components and quality of sugar beet plants. A split plot in stripe design with four replications was used, where nitrogen fertilizer treatments were occupied in the main plots and the bio-fertilizer (soil or spray) treatments were distributed in the sub-units (in the horizontal strips). The results could be summarized as follows:

- Increasing nitrogen fertilizer significantly increased the yield and its components traits, while the quality traits were decreased.

- The highest values for yield and its components traits were found either with yeast treatment or by using the mixture of macro \& micro spray treatment with amino acid treatment in the first or in the second season.

- The highest values of sugar beet quality traits were recorded by humic acid or by the effective microorganism treatment.

- Generally, the significant highest values of yield and its components traits either by using yeast treatment or by using the mixture of macro \& micro treatment with amino acid treatment together with $120 \mathrm{~kg} \mathrm{~N} / \mathrm{fed}$. While the quality traits had the highest values by using the mixture of macro \& micro treatment with amino acid treatment or by using the yeast treatment under $80 \mathrm{~kg} \mathrm{~N} / \mathrm{fed}$. treatment.

Key words: Mineral and bio-fertilization, quality traits of sugar beet.

\section{INTRODUCTION}

Sugar beet (Beta vulgaris L.) in Egypt is the second producing sugar crop after sugar cane. Sugar beet can grow well in fertile soil but it could be successfully grown also in newly reclaimed one which frequently is poor fertile. Therefore, efforts are focused on increasing the productivity of the crop by using the bio- and mineral nutrient as well as nitrogen fertilization.

Adequate soil fertility is one of the requirements for profitable sugar beet production. Nitrogen is the most yield limiting factor, but $\mathrm{N}$ management is critical to obtain optimum yield (Sharief et al., 1997; Hassanein and Hassouna, 2000) and crop quality (Badawi, 1996; Sarhan, 1998; Attia et al., 1999 and Basha, 1999). The distinct effect of nitrogen on top yield/fed., root yield $t / f e d$. and gross sugar yield t/fed., as well as the exhibited effect of nitrogen on root length, root diameter, foliage fresh weight/plant and root fresh

Fayoum J. Agric. Res. \& Dev., Vol. 26, No.1, January, 2012 
weight/plant found to be mainly due to the important role of nitrogen in plant growth and cell division (Ouda, Sahier, 2000; Nemat-Alaa, 2005; ElGeddawy et al., 2006; Badawi and Sead, 2008 and Hamada, 2009).

Biological fertilization plays a major role in crop production, in general, and with sugar beet, in particular. In this respect, Abou-Zaid, 1984; Mahmoud, 2001; and Mok and Mok, 2001; reported that the positive effect of yeast on rapeseed yield and its components maybe resulted in its action as a cofactor for ever 60 enzymes which catalyze many biochemical pathways involving amino acids and removing amine groups from amino acids to be used for energy that involved in several bioactivities including formation and maturation cells and for the making of all new cells by cell division. Shalaby and El-Nady (2008) found that foliar spraying yeast of $5 \mathrm{~g} / \mathrm{L}$ increased root length, root diameter, sucrose \%, plant survival root, sugar and yield ton/fed. Hamada (2009) mentioned that the application of amino acid and effective micro organisms as a foliar spray increased root fresh weight, root length, root diameter, sucrose \%, purity, root yield and sugar yield ton/fed.

Humic substances are an important soil component because it constitutes a stable fraction of carbon and improve water holding capacity (McDonnell $\boldsymbol{e t}$ al., 2001), as well as humic acid had a positive effect on plant growth demonstrated the importance of optimum mineral supply and independent of nutrition (Yildirim, 2007).

Accordingly, the present work aimed to study the response of sugar beet yield and quality to mineral and bio-fertilizer under the environmental conditions of El-Hamol, Kafr El-Sheikh Governorate.

\section{MATERIALS AND METHODS}

The present investigation was carried out in two successive seasons (2008/2009 and 2009/2010) in Agricultural Research Farm of Delta Sugar Company at El-Hamol, Kafr El-Sheikh Governorate to declare the effect of mineral and bio-fertilization on yield and its components and quality of sugar beet plants. Multigerm seeds Gloria of sugar beet (Beta vulgaris L.) imported from Germany were used.

This study included 24 treatments which were the combination between eight foliar spraying and field added application (Table 1) with spraying rate $400 \mathrm{~L} / \mathrm{fed}$ and three application levels of fertilization $(80,100$ and $120 \mathrm{~kg}$ $\mathrm{N} /$ fed.), as urea $(46 \% \mathrm{~N})$.

The experiment of field was ploughed twice, leveled and divided into ridged and plots. Each plot unit included 12 ridges $(60 \mathrm{~cm}$ apart, and $3 \mathrm{~m}$ long occupying an area of $21 \mathrm{~m}^{2}$ (1/200 fed.). The normal procedures of agronomic practices were done as usual in sugar beet fields. The recommended doses of phosphorus fertilizers (30 kg/fed.), Phosphorus was applied as super phosphate $\left(15 \% \mathrm{P}_{2} \mathrm{O}_{5}\right)$ at seed bed preparation.

Nitrogen fertilizer was added as urea $(46 \% \mathrm{~N})$ in two equal splits, i.e. after thinning (45 days from sowing) and 3 weeks later.

Fayoum J. Agric. Res. \& Dev., Vol. 26, No.1, January, 2012 
EFFECT OF MINERAL AND BIO-FERTILIZATION ON YIELD,....

Table 1. The form and rate of treatment application under study.

\begin{tabular}{|c|c|c|c|}
\hline Treatment & $\begin{array}{c}\text { Form of } \\
\text { application }\end{array}$ & $\begin{array}{c}\text { Rate of } \\
\text { application }\end{array}$ & Notes \\
\hline Mineral mixture & Field added & 1 ton/fed. & $\begin{array}{l}\text { Comprise of: C.N., D.N., } \\
\mathrm{SiO}_{2}, \mathrm{TiO}_{2}, \mathrm{Al}_{2} \mathrm{O}_{3}, \mathrm{Fe}_{2} \mathrm{O}_{3} \text {, } \\
\mathrm{MnO}_{\mathrm{LnO}} \mathrm{L}_{\mathrm{D}} \mathrm{I}, \mathrm{MagO}_{\mathrm{CaO}} \mathrm{CaO} \\
\mathrm{Na}_{2} \mathrm{O}, \mathrm{K}_{2} \mathrm{O}, \mathrm{P}_{2} \mathrm{O}_{5}, \mathrm{CI} \text { and } \\
\mathrm{SO}_{3} \text {. }\end{array}$ \\
\hline $\begin{array}{l}\text { Humic } \\
\text { composition }\end{array}$ & Field added & $1 \mathrm{~kg} / \mathrm{fed}$. & $\begin{array}{l}\text { Comprised of: Humic acid } \\
80 \% \text {, potassium oxide 10- } \\
15 \% \text { and Micro-elements } \\
1 \% \text {. }\end{array}$ \\
\hline \multirow{2}{*}{$\begin{array}{l}\text { Effective } \\
\text { Microorganisms } \\
\text { (EM) }\end{array}$} & Field added & $4 \mathrm{~L} / \mathrm{fed}$ & \multirow[b]{2}{*}{$\begin{array}{l}\text { Comprised of: } \\
\text { 1- Photosynthetic bacteria: } \\
\text { a- Radopsedomonas plustris } \\
\text { (ATCC 17001) } \\
\text { b- Rhadobacter sphacroder } \\
\text { (ATCC 17023) } \\
\text { 2- Lactic acid bacterial } \\
\text { a- Lactobacillus plantar } \\
\text { (ATCC 8014). } \\
\text { b- Lactobacillus casei (ATCC } \\
\text { 7469) } \\
\text { c- Streptococcus lactis (IFO } \\
\text { 12007) } \\
\text { 3- Yeasts } \\
\text { Saccharomyces cerevisia (IFO } \\
\text { 0203) } \\
\text { 4- Mycrorhiza produced during } \\
\text { EM industry }\end{array}$} \\
\hline & $\begin{array}{l}\text { Foliar } \\
\text { spraying }\end{array}$ & $2 \mathrm{~L} / \mathrm{fed}$. & \\
\hline \multirow[t]{2}{*}{ Yeast } & Field added & $5 \mathrm{~g} /$ liter & \\
\hline & Foliar spraying & $5 \mathrm{~g} /$ liter & \\
\hline $\begin{array}{l}\text { Amino acid } \\
\text { mixture (A) }\end{array}$ & $\begin{array}{l}\text { Foliar } \\
\text { spraying }\end{array}$ & $1 \mathrm{~g} /$ liter & $\begin{array}{l}\text { Comprised of: Therionine, } \\
\text { Aspartic, Serine, Glutamic, } \\
\text { Proline, Glycine, Alanine, } \\
\text { Arginine, Histidine, Cysteiene, } \\
\text { Valline, Methionine, } \\
\text { Isoliosine, Liosine, Tyrosine, } \\
\text { Phenyl alanine, Lysine. }\end{array}$ \\
\hline Nutrients (B) & $\begin{array}{l}\text { Foliar } \\
\text { spraying }\end{array}$ & $2 \mathrm{~g} /$ liter & $\begin{array}{l}\text { Comprised of } \mathrm{N}, \mathrm{P}, \mathrm{K}, \mathrm{Mg} \text {, } \\
\mathrm{S}, \mathrm{Cu}, \mathrm{B}, \mathrm{Fe}, \mathrm{Zn}, \mathrm{Mn} \text { and } \\
\text { Mo. }\end{array}$ \\
\hline $\begin{array}{l}\text { Amino acid }+ \\
\text { Nutrients }(\mathrm{A}+\mathrm{B})\end{array}$ & $\begin{array}{l}\text { Foliar } \\
\text { spraying }\end{array}$ & $1+2 \mathrm{~g} /$ liter & \\
\hline Control & \multicolumn{3}{|l|}{ Tap water } \\
\hline
\end{tabular}

A split-plot in strip design with four replications was used, where nitrogen fertilizer treatments were put in the main strips and the foliar spraying and field added application treatments in the horizontal strips.

Fayoum J. Agric. Res. \& Dev., Vol. 26, No.1, January, 2012 
Sugar beets were hand harvested, roots were taken from the six centers rows, then it were scrubbed free of soil and samples were taken to assess the quality parameters. Within $24 \mathrm{~h}$ of harvest the sucrose content and the other fresh sugar beets were determined at the sugar factory laboratory.

Soil analysis: soil samples were taken at random from the experimental field area at depth of $40 \mathrm{~cm}$ from soil surface and prepared for both mechanical and chemical analysis as shown in Table (2).

Table 2. Some physical and chemical properties of the experimental soil.

\begin{tabular}{|c|c|c|c|c|c|}
\hline \multirow[b]{2}{*}{ Soil property } & \multicolumn{2}{|c|}{ Value } & \multirow[b]{2}{*}{ Soil property } & \multicolumn{2}{|c|}{ Value } \\
\hline & $\begin{array}{l}2008 / \\
2009\end{array}$ & $\begin{array}{c}2009 / \\
2010\end{array}$ & & $\begin{array}{l}2008 / \\
2009\end{array}$ & $\begin{array}{l}2009 / \\
2010\end{array}$ \\
\hline Sand (\%) & 27.91 & 33.55 & $\mathrm{HCO}^{----}{ }_{3}(\mathrm{meq} / \mathrm{L})$ & 4.0 & 4.0 \\
\hline Silt (\%) & 28.32 & 21.49 & $\mathrm{SO}^{--}{ }_{4}(\mathrm{meq} / \mathrm{L})$ & 17.3 & 16.2 \\
\hline Clay (\%) & 43.77 & 44.96 & $\mathrm{~N}$ available (ppm) & 238 & 189 \\
\hline Texture grade & Clay & Clay & $\mathrm{P}$ available $(\mathrm{ppm})$ & 3.5 & 4.4 \\
\hline $\mathrm{pH}(1: 2.5$ suspension $)$ & 8.1 & 8.0 & $\mathrm{~K}$ available (ppm) & 37.5 & 38.2 \\
\hline $\mathrm{ECe}\left(\mathrm{dS} \mathrm{m}^{-1}\right)$ & 1.4 & 1.2 & Organic matter \% & 2.3 & 2.6 \\
\hline $\mathrm{Ca}^{++}(\mathrm{meq} / \mathrm{L})$ & 12.4 & 13.2 & $\mathrm{CEC}\left(\mathrm{c} \mathrm{mol}^{+} / \mathrm{kg}\right.$ soil $)$ & 76.9 & 76.2 \\
\hline $\mathrm{Mg}^{++}(\mathrm{meq} / \mathrm{L})$ & 7.2 & 5.8 & Fe available (ppm) & 2.9 & 3.9 \\
\hline $\mathrm{Na}^{+}(\mathrm{meq} / \mathrm{L})$ & 1.9 & 1.5 & $\mathrm{Cu}$ available (ppm) & 2.8 & 2.8 \\
\hline $\mathrm{K}^{+}(\mathrm{meq} / \mathrm{L})$ & 0.2 & 0.2 & Zn available (ppm) & 1.3 & 1.1 \\
\hline $\mathrm{Cl}^{-}(\mathrm{meq} / \mathrm{L})$ & 0.4 & 0.6 & Mn available (ppm) & 3.4 & 5.2 \\
\hline
\end{tabular}

\section{Studied characters:}

\section{A- Yield and yield components:}

At harvesting time (210 days): Sugar beet plants in six ridges of each plot unit were collected and cleaned; then roots and tops were separated and each was weighted in $\mathrm{kg}$.

1 - Root length (cm).

3- Foliage fresh weight (g/plant)

5- Root yield (t/fed.).

2- Root diameter $(\mathrm{cm})$.

4- Root fresh weight (g/plant).

6- Top yield (t/fed.)

7- Gross sugar yield (t/fed.) which was calculated as follow:

\section{B-Yield quality:}

$$
=\text { root yield } \mathrm{t} / \text { fed. } \mathrm{x} \text { gross sugar } \%
$$

A sample of 30 roots were taken and sent to full automatic sugar laboratory of Delta Sugar Company to determine the following parameters:

1 - Gross sugar \% per beet (pol reading \%).

2- Loss sugar \%:

$$
\text { Loss sugar = gross sugar } \% \text { - white sugar } \%
$$

3- Quality \% (QZ)

$$
\mathrm{QZ}=\frac{\mathrm{ZB}}{\mathrm{Pol}} \times 100
$$

$\mathrm{ZB}=$ Corrected sugar content $(\%$ beet $)$.

Pol $=$ Gross sugar $\%$

\section{Statistical analysis:}

The obtained data were subjected to a proper statistical analysis according to the procedure outlined by Gomez and Gomez (1984) and means of the

Fayoum J. Agric. Res. \& Dev., Vol. 26, No.1, January, 2012 
EFFECT OF MINERAL AND BIO-FERTILIZATION ON YIELD,....

different treatments were compared using least significant difference (LSD) test at 5\% level of probability. Analysis of variance technique was done by means of "MSTAT" computer software package.

\section{RESULTS AND DISCUSSION \\ The main effects}

Data in Table 3 show that the all studied traits; root length, root diameter, foliage fresh weight, root fresh weight, top yield, root yield; gross sugar yield and sugar loss \%; were highly significantly affected by nitrogen fertilizer in the two growing seasons, except root diameter and sugar loss $\%$ in the first sea one. On the other hand, juice quality and white sugar loss \% were insignificantly affected by nitrogen fertilizer in the two growing seasons.

Generally, increasing nitrogen fertilizer from 80 up to $120 \mathrm{~kg} \mathrm{~N} / \mathrm{fed}$. significantly increased the all studied traits, while the quality traits were decreased by increasing the nitrogen fertilizer. These results mean that application of $120 \mathrm{~kg} \mathrm{~N} / \mathrm{fed}$. produced the highest values of the all yielding studied traits, While the quality traits showed by the application of $80 \mathrm{~kg}$ $\mathrm{N} / \mathrm{fed}$. gave the highest values in the two growing seasons. The exhibited effect of nitrogen on root length and root diameter may be mainly due to the effective role of nitrogen in plant metabolism and the production of IAA which play a distinct role in plant growth. The same findings are obviously obtained by Badawi and Seadh. (2008) and Hamada (2009). As well as, the highest values of foliage fresh weight/plant and root fresh weight/plant may be assured the pronounced effect of nitrogen element in plant and the effect of nitrogen on root dimension. These results are in agreement with those reported by Ouda, Sohier (2000) and Nemeat-Alla (2005) who found that foliage fresh weight/plant and root fresh weight/plant increased by increasing levels of nitrogen.

El-Geddawy et al. (2006) suggested that the distinct effect of nitrogen on top yield $t /$ fed., root yield $t / f e d$. and gross sugar yield $t / f e d$. was mainly due to the important role of nitrogen in plant growth and cell division. This may be ascribed to increment chlorophyll concentration in leaves, photosynthesis process and activation of accumulation of carbohydrates.

On other hand, the response of gross sugar \%, juice quality, and white gross \% were irreversible with increase in N-levels. These traits tended to be decreased with increasing nitrogen levels. This finding reflected the bad effect of excess amount of nitrogen on the quality of sugar beet juice. This means that it must be to carry out soil analysis to determine the suitable applied $\mathrm{N}$ dose to sugar beet crop to avoid this bad effect on juice quality. These results are in coincidence with that reported by Badawi (1996) who found that the reduction in juice quality \% of sugar beet resulted from increasing N-level. Basha (1999) mentioned that the highest values of juice quality of sugar beet were obtained by $60 \mathrm{~kg} \mathrm{~N} / \mathrm{fed}$.

Data in Table (3) reveal that the bio- and mineral nutrient had a highly significant effect on most of the studied traits; root length, root diameter, foliage fresh weight, root fresh weight, top yield, root yield, gross sugar yield and sugar loss $\%$ in the two growing seasons, except root diameter and sugar loss $\%$ in the first season. On the other hand, juice quality and white sugar loss\% showed insignificant influence by this trial in the two growing seasons, Generally, the highest values for root length and root diameter were recognized by using the yeast (soil + spray) treatment in the first season $(40.5$ and $13.2 \mathrm{~cm})$

Fayoum J. Agric. Res. \& Dev., Vol. 26, No.1, January, 2012 
or by using the mixture between macro \& micro spray and amino acid spray in the second season $(43.8$ and $15.2 \mathrm{~cm})$, respectively. As well as, the highest values for foliage fresh weight and root fresh weight were obtained by using the yeast spray (186.4 and 992.7 g/plant and 225.9 and $1017 \mathrm{~g} / \mathrm{plant}$ ) in the first and the second seasons, respectively.

As for the yield, the highest values of top yield, root yield and gross sugar yield were recorded by using the yeast either added in soil or spray $(5.84,31.11$ and $6.37 \mathrm{t} / \mathrm{fed}$.) and $(7.28,32.59$ and $6.16 \mathrm{t} / \mathrm{fed})$ in the first and the second seasons, respectively. The positive effect of yeast on yield and its components may be due to its role for encourage the enzymes which catalyze many biochemical bathways involving amino acids and removing amino groups from amino acid for energy that involved in several bioactivities including formation and maturation cells and cell division. Shalaby and El-Nady (2008) mentioned that foliar spring yeast of $59 \mathrm{~g} / \mathrm{L}$ increased root length, root diameter and yield ton/fed. Also, Hamada (2009) found that the application of amino acid increased root fresh weight, root length, root diameter, root yield ton/fed.

On the other hand, the sugar loss $\%$ per beet showed highly significant effect caused by the biofertilizer. The highest values were recorded by Humic acid treatment or by effective micro organisms treatment (2.84 and $2.74 \%$ ) respectively in the second season only. Humic acid had a positive effect on plant growth demonstrated the importance of optimum mineral supply and independent of nutrition (Yildirim, 2007). Hamada (2009) found that application of effective micro organisms increased sucrose $\%$.

\section{Interaction effect:}

Data in Table (4) reveal that the interaction between nitrogen fertilizer with biofertilizer had a highly significant effect on yield components traits i.e. root diameter $(\mathrm{cm})$ in the second season only, foliage fresh weight $(\mathrm{g} / \mathrm{plant})$ and root fresh weight (g/plant) in the first season only. Also, the yield traits i.e. root yield $(\mathrm{t} / \mathrm{fed}$.) and gross sugar yield ( $\mathrm{t} / \mathrm{fed}$.) were highly significant influenced by the first order interaction in the two growing seasons, While the top yield (t/fed.) was highly significant affected in the first season only. As for, the quality sugar beet traits i.e. juice quality $\%$ and white sugar $\%$ were significantly affected by the first order interaction in the first season only.

For the yield components, the highest value for root diameter $(17.40 \mathrm{~cm})$ was detected by the mixture of macro and micro spray and amino acid under $120 \mathrm{~kg} \mathrm{~N} / \mathrm{fed}$., while the highest values for foliage fresh weight $(250.3 \mathrm{~g})$ and root fresh weight (1164.5 g) were recorded by the yeast (soil + spray) treatment under $120 \mathrm{~kg} \mathrm{~N} /$ fed.

For the yield, the highest values for top yield (7.95 ton/fed.) in the first season, root yield (36.91 and 37.10 t/fed.) and gross sugar yield (7.43 and 7.02 $\mathrm{t} /$ fed.) in the first and the second seasons, respectively, were detected by using yeast (soil + spray) treatment under $120 \mathrm{~kg} \mathrm{~N} / \mathrm{fed}$.

As for, the quality the highest values for juice quality \% $(87.13 \%)$ were recorded by the mixture of macro and micro (spray) and amino acid (spray) in the first season, while white sugar \% $(17.69 \%)$ were recorded by using yeast (soil + spray) in the second season under $80 \mathrm{~kg} / \mathrm{fed}$.

Fayoum J. Agric. Res. \& Dev., Vol. 26, No.1, January, 2012 
Table 3

Fayoum J. Agric. Res. \& Dev., Vol. 26, No.1, January, 2012 
Cont.Table 3

Fayoum J. Agric. Res. \& Dev., Vol. 26, No.1, January, 2012 
Table 4

Fayoum J. Agric. Res. \& Dev., Vol. 26, No.1, January, 2012 


\section{CONCLUSION}

From the results of this study, it could be concluded that, generally, the highest values of yield and its component were produced by using $120 \mathrm{~kg}$ N/fed. either with the yeast treatment or with the mixture of macro and micro (spray) with amino acid in the two growing seasons. Therefore, these treatments may be recommended for sugar beet production for high yielding capacity under El-Hamol, Kafr El-Sheikh condition.

\section{REFERENCES}

Abou-Zaid, M. (1984). Biochemical studies on fooder yeast. Ph.D. Thesis, Fac. Agric., Cairo Univ., Egypt.

Attia, A.M.; A.T. El-Kassaby; M.A. Badawi and S.S. Seaadh (1999). Yield, yield components and quality of sugar beet as affected by growth regulators, and nitrogen fertilization. Proc. of the $1^{\text {st }}$ Inter. Conf. on Sugar \& Integrated Industries, Present \& Future, 15-18 ${ }^{\text {th }}$ February, 1999, Luxor, Egypt.

Badawi, M.A. (1996). Effect of soil and foliar fertilization with urea on yield, yield components and quality of sugar beet (Beta vulgaris, L.). J. Agric. Sci. Mansoura Univ., 21 (9): 3083-3096.

Badawi, M.A. and S.E. Sead (2008). Effect of soil type on root sugar yield and juice quality parameters of some sugar beet cultivars. The $4^{\text {th }}$ Arab Mansoura Conf. of Food and Dairy Sci. \& Tech., 10-14 November.

Basha, H.A. (1999). Response of two sugar beet cultivars to level and method of nitrogen application in sandy soil. Zag. J. Agric. Res., 26 (1): 11-26.

El-Geddawy, I.H.; A.M.A. El-Shafai and N.B. Azzazy (2006). Yield and quality of some sugar beet varieties as affected by planting densities and nitrogen fertilization. J. Agric. Sci. Mansoura Univ., 31 (1): 43-54.

Gomez, K.A. and A.A. Gomez (1984). Statistical Procedures for Agricultural Reach. A Wiley Inter Science Publication. John Wily and Sons. Inc., New York, U.S.A.

Hamada, A.M.A. (2009). Agronomic studies on sugar beet. M.Sc. Thesis, Fac. of Agric., Mansoura Univ., Egypt.

Hassanein, M.A. and M.G. Hassouna (2000). Effect of bio- and mineral nitrogen fertilization on sugar beet yield and quality in the new reclaimed areas at Nubaria region. Alex. Sci. Exch., 21 (2): 153-161.

Mahmoud, T.R. (2001). Botanical studies on growth and germination of Magnolia "Magnolia grandiflora L." plants. Ph.D. Thesis, Fac. Agric. Moshtohor, Zagazig Univ., Egypt.

McDonnell, R.; N.M. Holden; S.M. Ward; J.F. Collins; E.P. Farrell and M.H.B. Hayes (2001). Characteristics of humic substances in health land and forested peat soils of the wicklow mountains. Biology and Environ. 101 (3): 187-197.

Mok, D.W.S. and Mok M.C. (2001). Cytokinin metabolism and action. Ann. Rev. Plant Physiol. Mol. Biol. 52: 149-156.

Nemeat-Alla, E.A.E. (2005). Yield and quality of sugar beet as affected by different nitrogen and sulphur rates under clay soils. J. Agric. Sci. Mansoura Univ., 30 (12): 7255-7264.

Ouda, Sohier, M.M. (2000). Effect of nitrogen fertilization with micronutrient on yield and quality of sugar beet in yield and quality of sugar beet in newly reclaimed land. Zag. J. Agric. Res., 27:

Fayoum J. Agric. Res. \& Dev., Vol. 26, No.1, January, 2012 
Sarhan, H.M. (1998). Macro-elements requirements of sugar beet. M.Sc. Thesis, in Agron., Fac. Agric., Mansoura Univ., Egypt.

Shalaby, M.El.S. and M.F. El-Nady (2008). Application of Saccharomyces cerevisiae as a biocontrol agent against Fusarium infection of sugar beet plants. Acta Biologica Szegediensis 52 (2): 371-357.

Sharief, A.E.; E.A. Mohamed and S.M. Salama (1997). Evaluation of some sugar beet cultivars to NPK-fertilizers and yield analysis. J. Agric. Sci., Mansoura Univ., 22 (6): 1887-1903.

Yildirim, E. (2007). Foliar and soil fertilization of humic acid affect productivity and quality of tomato. Acta Agr. Scandinavica. Section B. Soil and Plant Sci., 57 (2): 182-186.

تأثير التسميد المعدني والحيوي علي المحصول ومكوناته وصفات الجودة لبنجر السكر

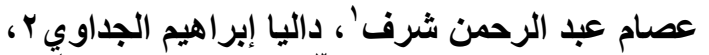

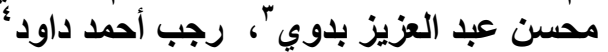

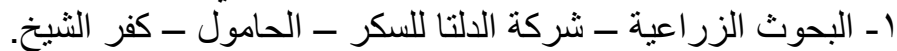

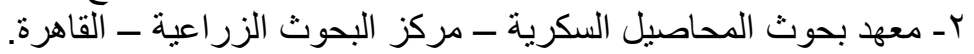

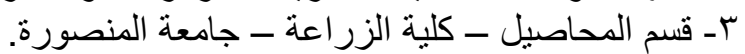

$$
\begin{aligned}
& \text { عـ قسم المحاصيل - كلية الزر اعة - جاعيل جامعة أسيوط. }
\end{aligned}
$$

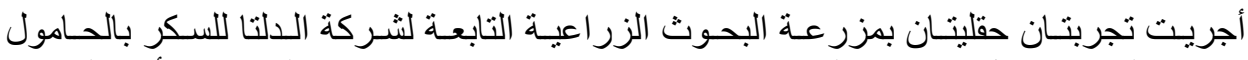

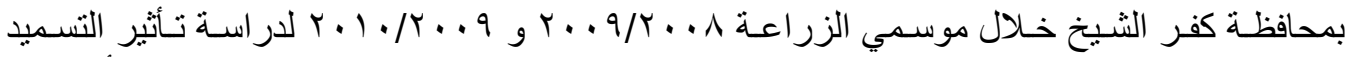

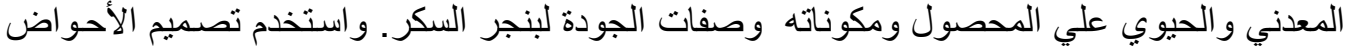

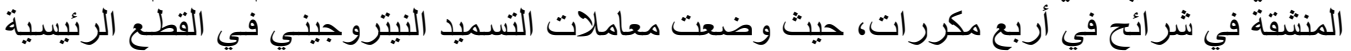

$$
\begin{aligned}
& \text { ووزعت معاملات التسميد الحيوي في القطع المنشقة (في الوضع الأفقي للشر ائح). } \\
& \text { ويمكن تلخيص النتائج كما يلي: }
\end{aligned}
$$

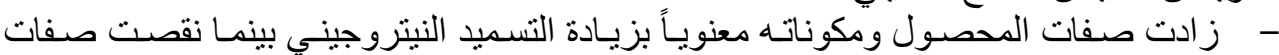
الجودة بزيادة التسميد النيتروجيني.

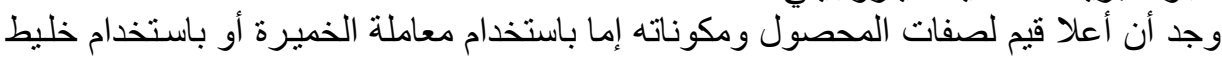

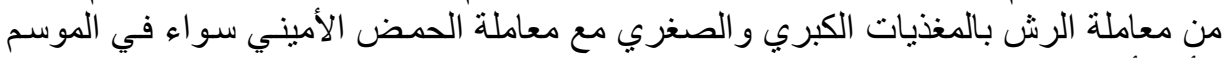
الأول أو الثاني.

- - سـلت أعـلا ألقيم لصـفات الجـودة باسـتخدام معاملـة حمض الهيومـك أو معاملـة العضـيات

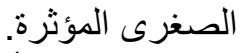

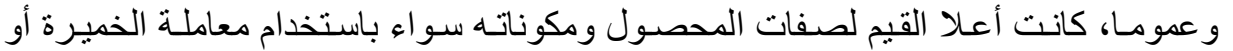

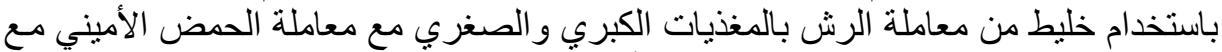

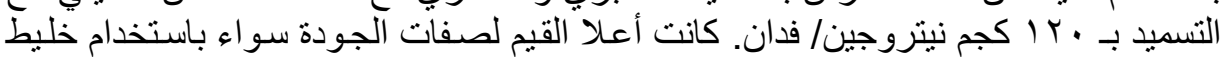

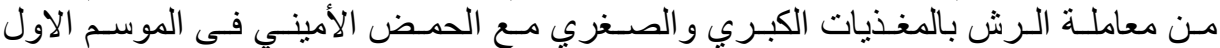

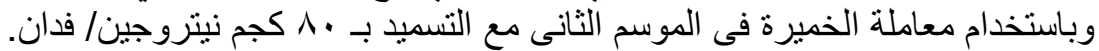

Fayoum J. Agric. Res. \& Dev., Vol. 26, No.1, January, 2012 